\title{
Aktaş Gölü (Ardahan) Yüzey Sularındaki Besleyici Elementlerin Yaz Dinamiklerinin Coğrafi Bilgi Sistemleri ile İncelenmesi
}

\author{
Investigating Summer Dynamics of the Nutrients in Lake Aktaş (Ardahan) Surface Water, \\ Using Geographic Information Systems
}

\author{
Serkan KÜKRER ${ }^{1}$ (D), Şakir FURAL ${ }^{2}$ (1), Dilek AYKIR ${ }^{3}$ (I)
}

${ }^{1}$ Doç. Dr., Ardahan Üniversitesi, İnsani Bilimler ve Edebiyat Fakültesi, Coğrafya Bölümü, Ardahan, Türkiye

${ }^{2}$ Arş. Gör. Dr., Kırşehir Ahi Evran Üniversitesi, Fen - Edebiyat Fakültesi, Coğrafya Bölümü, Kırşehir, Türkiye

${ }^{3}$ Dr. Öğr. Üyesi, Ardahan Üniversitesi, İnsani Bilimler ve Edebiyat Fakültesi, Coğrafya Bölümü, Ardahan, Türkiye

ORCID: S.K. 0000-0001-6924-3199; Ş.F. 0000-0002-1603-2424; D.A. 0000-0002-2748-4055

\section{Öz}

Aktaş Gölü; 11.7 km²'si Türkiye'de Ardahan ilinde, 13.8 km²'si Gürcistan'da yer alan toplam 25.5 km² alan kaplayan tektonik kökenli bir göldür. Bu çalışmada, gölün ekolojik özelliklerinin korunması ve sürdürülebilir kullanımın sağlanması açısından oldukça önemli bir faktör olan su kalitesi incelenmiştir. Çalışmada, su kalitesinin ve gölün ekolojik özelliklerinin bozulmasına neden olabilecek besleyici element konsantrasyonlarının zamansal ve mekânsal değişiminin Coğrafi Bilgi Sistemleri ile analiz edilmesi amaçlanmıştır. Çalışma kapsamında; Aktaş Gölü üzerinde mekânsal analizlere uygun aralıklarla seçilen 9 örnekleme noktasından 2014 yılı haziran, temmuz, ağustos aylarında yüzey suyu örneği toplanmıştır. Örnekler üzerinde sıcaklık, pH, çözünmüş oksijen, amonyum azotu, nitrat azotu, nitrit azotu ve fosfat ölçümleri yapılmıştır. Sonuçlar T.C. Tarım ve Orman Bakanlığı tarafından yayınlanan Yüzeysel Su Kalitesi Yönetimi Yönetmeliği'nde belirlenmiş olan konsantrasyonlarla karşılaştııımıştır. Elde edilen bulgulara göre; Aktaş Gölü yüzey sularının oksijen, amonyum ve nitrat azotu açısından I. sınıf (kirlenmemiş), nitrit azotu açısından ise II. sınıf (az kirlenmiş su) grubuna girdiği belirlenmiştir. Aktaş Gölü'nde örneklemesi $2004-2005$ yılında gerçekleştirilen çalışmayla (Özbay ve Kılınç 2008) yapılan karşılaştırmalara göre amonyum ve fosfat seviyelerinin geçen 10 yıllık periyotta oldukça arttığı tespit edilmiştir.

Anahtar kelimeler: Sulak alan ekolojisi, Bölgesel ekolojik risk, Coğrafi Bilgi Sistemleri

\section{ABSTRACT}

Lake Aktaş is a tectonic lake with a total surface area of $25.5 \mathrm{~km}^{2}\left(11.7 \mathrm{~km}^{2}\right.$ in Ardahan, Turkey; $13.8 \mathrm{~km}^{2}$ in Georgia). This study investigated water quality of the lake, a crucial element in protecting the ecological characteristics of a lake, and ensuring its sustainable use. The study involved use of Geographical Information Systems software to analyze the temporal and spatial changes in nutrient element concentrations that may deteriorate water quality and ecological characteristics of the lake. In the framework of the study, surface water samples were collected on the Lake Aktaş in June, July, and August 2014 from nine stations selected at intervals in accordance with spatial analysis. The collected samples were measured for temperature, $\mathrm{pH}$, dissolved oxygen, ammonium nitrogen, nitrate nitrogen, nitrite nitrogen, and orthophosphate. The obtained results were compared with the concentrations specified in Surface Water Quality Management Regulation published by the T. R. Ministry of Agriculture and Forestry. According to the findings, surface water classification and distribution for Lake Aktaş included the following categories class I (WS-I/natural) in terms of oxygen, ammonium, and nitrate nitrogen, and class II (WS-II/undeveloped) in terms of nitrite. It was found that ammonium and phosphate levels have considerably increased in the last ten years, based on the comparisons made with the study sampled in Aktaş Lake during 2004-2005 (Özbay and Kılınç 2008).

Keywords: Wetland ecology, Regional Ecological Risk, Geographical Information Systems

Başvuru/Submitted: 22.02.2021 • Revizyon Talebi/Revision Requested: 11.05.2021 • Son Revizyon/Last Revision Received: 18.05 .2021 • Kabul/Accepted: 02.06 .2021

Sorumlu yazar/Corresponding author: Şakir FURAL / furalsakir@gmail.com

Atıf/Citation: Kukrer, S., Fural, S., \& Aykir, D. (2021). Aktaş gölü (Ardahan) yüzey sularındaki besleyici elementlerin yaz dinamiklerinin coğrafi bilgi sistemleri ile incelenmesi. Cografya Dergisi, 42, 283-294. https://doi.org/10.26650/JGEOG2021-884743 


\section{EXTENDED ABSTRACT}

The quantity and quality of water resources are gradually decreasing because of natural-anthropogenic effects. Considering that the world population is constantly increasing and the quantity and quality of water resources are rapidly decreasing, access to potable water will be a major global problem in the coming years. According to Falkenmark Indicators, Turkey is a "water-stressed" country, which will soon face water shortages. Hence, it is imperative to employ analytical studies to explore the factors that threaten the ecological characteristics of water resources and to eliminate the detected risks in a short time. This study examined water quality, which is a very important indicator in protecting the ecological characteristics of lakes and ensuring their sustainable use.

Lake Aktaş, which was selected as the study area, has a tectonic origin with a total surface area of $25.5 \mathrm{~km}^{2}$ of which $11.7 \mathrm{~km}^{2}$ is in Ardahan, Turkey and $13.8 \mathrm{~km}^{2}$ is in Kartsakhi, Georgia. The geopolitical feature of the lake is significant in monitoring the pollutant and nutrient elements that may arrive from the Georgian border. By using Geographical Information Systems software, the study aimed to analyze the temporal and spatial change in nutrient element concentrations that may cause deterioration of water quality and ecological characteristics of the lake. In the present framework, surface water samples were collected on the Lake Aktaş in June, July, and August 2014 from nine stations that were selected at intervals in accordance with spatial analysis. The collected samples were measured for temperature, $\mathrm{pH}$, dissolved oxygen, ammonium nitrogen, nitrate nitrogen, nitrite nitrogen, and orthophosphate. Based on the findings, it was concluded that lake water temperature was in the range $15^{\circ} \mathrm{C}-22.5^{\circ} \mathrm{C}$ in the three-month period in which measurements were carried out. The $\mathrm{pH}$ concentration was found to be in the range $8.67-9.63$, dissolved oxygen was measured to be $6.5-10 \mathrm{mg} / \mathrm{L}$, nitrite in $0.02-$ $0.081 \mathrm{mg} / \mathrm{L}$, nitrate in $0.001-0.096 \mathrm{mg} / \mathrm{L}$, and ammonium in $0.013-0.428 \mathrm{mg} / \mathrm{L}$. Phosphate concentration was in the range $0.111-0.256$ $\mathrm{mg} / \mathrm{L}$, and N/P ratio and total inorganic nitrogen (TIN) were $0.16-3.57$ and $0.101-0.489 \mathrm{mg} / \mathrm{L}$ respectively.

The research findings were compared with the concentrations specified in Surface Water Quality Management Regulation published by the T. R. Ministry of Agriculture and Forestry. Per the findings, surface water classification and distribution for Lake Aktaş included the following categories: WS-I (natural) in terms of oxygen, ammonium, and nitrate nitrogen, and WS-II (undeveloped) in terms of nitrite.

According to statistical analysis data, a correlation was observed between nitrite nitrate and nitrate ammonium, while phosphate was not associated with nitrogenous nutrients. The high correlation between nitrogen and phosphorus (N/P) and TIN revealed that changes in the N/P ratio were largely due to the changes in nitrogenous nutrients. $\mathrm{pH}$ was found to increase with increase in nitrite and nitrate. According to factor analysis, it was determined that nitrite, nitrate, ammonium, and phosphate had different processes and sources.

Based on the comparisons made with the study sampled in Aktaş Lake in 2004-2005, ammonium and phosphate levels have considerably increased in the last 10 years (Özbay and Kılınç 2008). Based on the analyses conducted in the study, no finding pointed to ecological problems in Lake Aktaş' surface water. However, a finding in a study conducted 10 years ago that identified increase in nutritive element concentration in the lake indicates that possible deterioration in the ecological structure of the water should be closely monitored. The following measures are suggested to maintain water quality and the ecological structure of Lake Aktaş:

- Prevent domestic waste discharge into the lake through compulsory and regular inspections.

- Store the dung collected from the cattle for burning in winter months in proper condition to prevent them from reaching the lake by means of rain water.

- Arrange the watering areas of cattle that come to the shore in large flocks to drink water in other areas that are farther from the lake.

- Conduct analysis of the ecological changes that may occur in the lake if the Aktaş border gate is reopened and the highway traffic near the lake becomes denser.

- Perform the required analyses periodically by sampling at regular intervals, especially from the sampling points close to the border region, to monitor the pollutants discharged from the Georgian border into the lake.

- Conduct necessary studies to strengthen the national and international protection status of the lake. 


\section{GÍRIŞ}

Su kaynaklarının miktarı ile kalitesi doğal ve antropojenik etkilerle gittikçe azalmaktadır. Dünya nüfusunun sürekli arttığı, su kaynaklarının miktarı ve kalitesinin hızla azaldığı düşünüldüğünde, gelecek yıllarda temiz ve kaliteli suya erişimin önemli bir küresel sorun olacağını tahmin etmek zor değildir. Türkiye küresel havza ölçeğinde Akdeniz havzasında yer alan, Falkenmark su varlığı göstergesine göre su sıkıntısı çeken ve su kıtlığına doğru sürüklenen bir ülkedir (Falkenmark, Lundqvist ve Widstrand, 1989). Bazı bilimsel çalışmalar Türkiye'de son yıllarda çok sayıda sulak alanın kuruyarak yok olduğunu doğrulamakta ve bu sürecin önlem alınmaması durumunda hızlanarak devam edeceğini göstermektedir (Aydın, Ünaldı, Duman, Çiçek ve Türkoğlu, 2017). Sulak alanları tehdit eden tek sorun su kıtlığı nedeniyle kuruyarak yok olmak değildir. Sulak alanlarda su kalitesinde meydana gelen fiziksel ve kimyasal değişiklikler ekolojik yapıyı bozan sorunların ortaya çıkmasına neden olmaktadır. Sulak alanlarda; canlıların yaşam kaynaklarına zarar veren, insan sağlığını ve biyolojik çeşitliliği tehlikeye düşüren, direkt ya da dolaylı yollardan sulak alan ekosistemine katılarak suyun kalitesini bozan antropojenik kökenli maddelerin ortaya çıkardığı sorunlar su kirliliği olarak tanımlanmaktadır (Meyer ve Köster 2000).

Göl sularının fiziksel ve kimyasal özelliklerinin değişerek ekolojik yapının bozulmasında akarsular ve atmosferik olaylar oldukça önemli etkiye sahiptir (Ünlü, Çoban ve Tunç, 2008). Özellikle kapalı havza göllerinde akarsular tarafindan taşınan kirleticiler, organik maddeler ve besleyici elementler (nutrient) doğrudan göl sularına karışır. Akarsuların askıda ve çözünmüş halde taşıyarak göle deşarj ettiği maddeler suya karışır, ardından zaman içerisinde çökelerek sedimentin yapısına katılır. Su kalitesinin bozulması sulak alanlarda yaşayan fauna ve flora türlerinin yaşam koşullarının hızla değişmesine neden olur. Bu durum, yeni şartlara adapte olamayan türlerin zamanla yok olmasına yol açar ve sulak alanlarda ekolojik yapı bozulmaya başlar. Ekolojik yapının bozulmasının kaçınılmaz bir sonucu olarak biyoçeşitlilik azalma eğilimine girer (Taş, 2011). Sulak alanlarda birincil üretimde meydana gelen fiziksel ve kimyasal değişimlerden ilk etkilenen tür fitoplanktik canlılardır. Bu nedenle fitoplanktik canlılar kirletici kaynakların saptanmasında indikatör organizma olarak kullanılmaktadır. Göl sularında fitoplankton komünitesinin değişmesi, önceden tahmin edilemeyen alg artışlarını meydana getirir (Meyer ve Köster, 2000). Fitoplankton komünitesinin artmas1 sonucunda su bulanıklaşır, sahile vuran algler ile diğer canlılar çürüyerek kötü kokuya neden olur. Alg ve diğer canlı kalıntılarının suyun dibine çökerek organik süreçleri hızlandırmaları sulak alan ekosistemindeki oksijenin tükenmesine sebep olur (Şengörür ve Demirel, 2002). Kirlenmiş sulak alanlarda bitkiler ve hayvanların yanında besin zinciri yoluyla insanlar da zarar görür. Bu durum, sulak alanların ekolojik özelliklerini kaybederek uluslararası ölçekte değerinin azalmasına ve insanlar açısından sürdürülebilir kullanımın son bulmasına yol açabilir. Bahsi geçen sorunların çözülmesi ya da ortaya çıkmasının engellenmesi için sulak alanlarda analitik yöntemlere dayalı bilimsel çalışmaların yapılması ve risk faktörlerinin önceden tespit edilmesi gerekmektedir. Besin zincirinin ilk halkasını oluşturan bitkilerin kullandığı azot türleri ve fosfor besleyici elementlerdir. Doğal seviyelerdeki azot ve fosfor ekosistem için zararlı değildir. Endüstriyel, evsel ve tarımsal kökenli kirletici kaynaklar sulak alanlara antropojenik azot ve fosfor girişini arttırmaktadır. $\mathrm{Bu}$ nedenle, sulak alanlarda azot, fosfor ve diğer nutrient konsantrasyonlarında zenginleşme ortaya çıkar. Sulak alan ekosistemlerinde ekolojik yapının bozulma sürecinin ilk basamağını besleyici element zenginleşmesi oluşturur ve bu süreç aşırı alg çoğalmasıyla devam eder. Bu şekilde başlayan ekolojik yapı bozulmasının ileri evrelerinde ise oksijen tükenmesinin başlaması, oksijensiz süreçlerin hâkim olması, hidrojen sülfür, metan gibi zehirli gazların artışıla sulak alan ekosistemlerinde tür çeşitliliğinde ciddi seviyede azalma görülür. Bu yüzden; amonyum, nitrat, nitrit gibi azotlu nutrientlerin ve fosfat dinamiklerinin analitik yöntemlere dayalı bilimsel çalışmalarlatakip edilmesi, ekosistem kalitesive sürdürülebilirliği açısından oldukça önemlidir. Bahsi geçen nutrientlerin sulak alan ekosistemindeki zamansal ve mekânsal değişimlerinin izlenmesi antropojenik kaynak tanımlaması ve sorunlara etkin çözüm önerilerinin sunulabilmesi açısından önemlidir.

Bu çalışmada, Türkiye - Gürcistan sınırında yer alan, iki farklı ülkeye ait olmak gibi ilgi çekici aynı zamanda hassas bir jeopolitik konumu olan Aktaş Gölü yüzey sularının nutrient dinamiklerinde yaz aylarında görülen zamansal ve mekânsal değişimlerin CBS ve çok değişkenli istatistiksel analizler kullanılarak incelenmesi, elde edilen bulguların Aktaş Gölü'ne ait eski veriler ve T.C. Tarım ve Orman Bakanlığı'nın belirlediği su kalitesi standartları ile karşılaştırılarak gölün su kalitesinin tespit edilmesi amaçlanmıştır.

\subsection{Aktaş Gölü'nün konumu ve genel Coğrafi özellikleri}

Aktaş Gölü; Türkiye'nin doğusunda, Ardahan'ın Çıldır ilçesi ile Gürcistan sınırında yer almaktadır. $25.5 \mathrm{~km}^{2}$ alan kaplayan gölün $11.7 \mathrm{~km}^{2}$ 'si Türkiye, $13.8 \mathrm{~km}^{2}$ 'si Gürcistan sınırları içerisindedir (Şekil 1). Hazapin Gölü olarak da bilinen Aktaş 


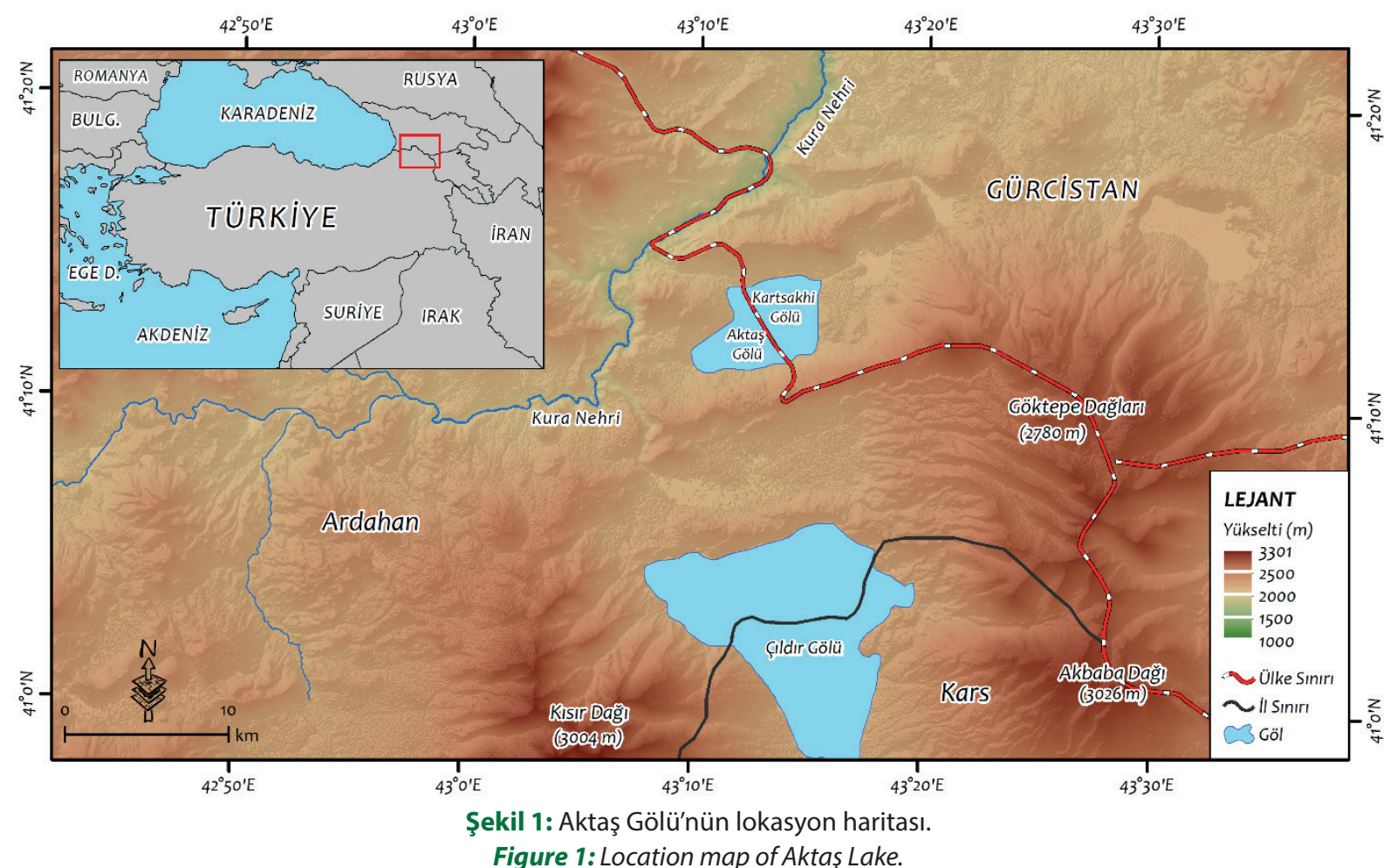

Gölü, Van Gölü'nden sonra Doğu Anadolu Bölgesi'nin ikinci büyük sodalı gölüdür. Göl, Kenarbeli köyü yakınlarındaki kısa boylu mevsimlik dereler ile güney kıyılardaki Ema, Ortaklı ve Güngörmez pınarlarından beslenmektedir (Doğanay ve Zaman, 2006). Bahsi geçen kaynaklara ek olarak ilkbahardaki kar erimeleri gölün diğer önemli beslenme kaynaklarındandır. Göl içerisinde bir kısmı tamamen kayalık olan 13 ada yer almaktadır.
$\mathrm{Bu}$ adalardan en önemlileri Büyük Ada, Kaçak Ada, Başak Ada ve Ufak Ada'dır (Şekil 2). Adalarda yerleşme ve antropojenik faaliyet yoktur.

Aktaş Gölü'nün kıyı çizgisi çevresi Pliyosen'e ait karasal kırıntılar ile kaplıdır. Gölün kuzeyinde Neojen'e ait volkanitler, güneyinde Kuvaterner'e ait volkanitler, batısında ise üst Miyosen

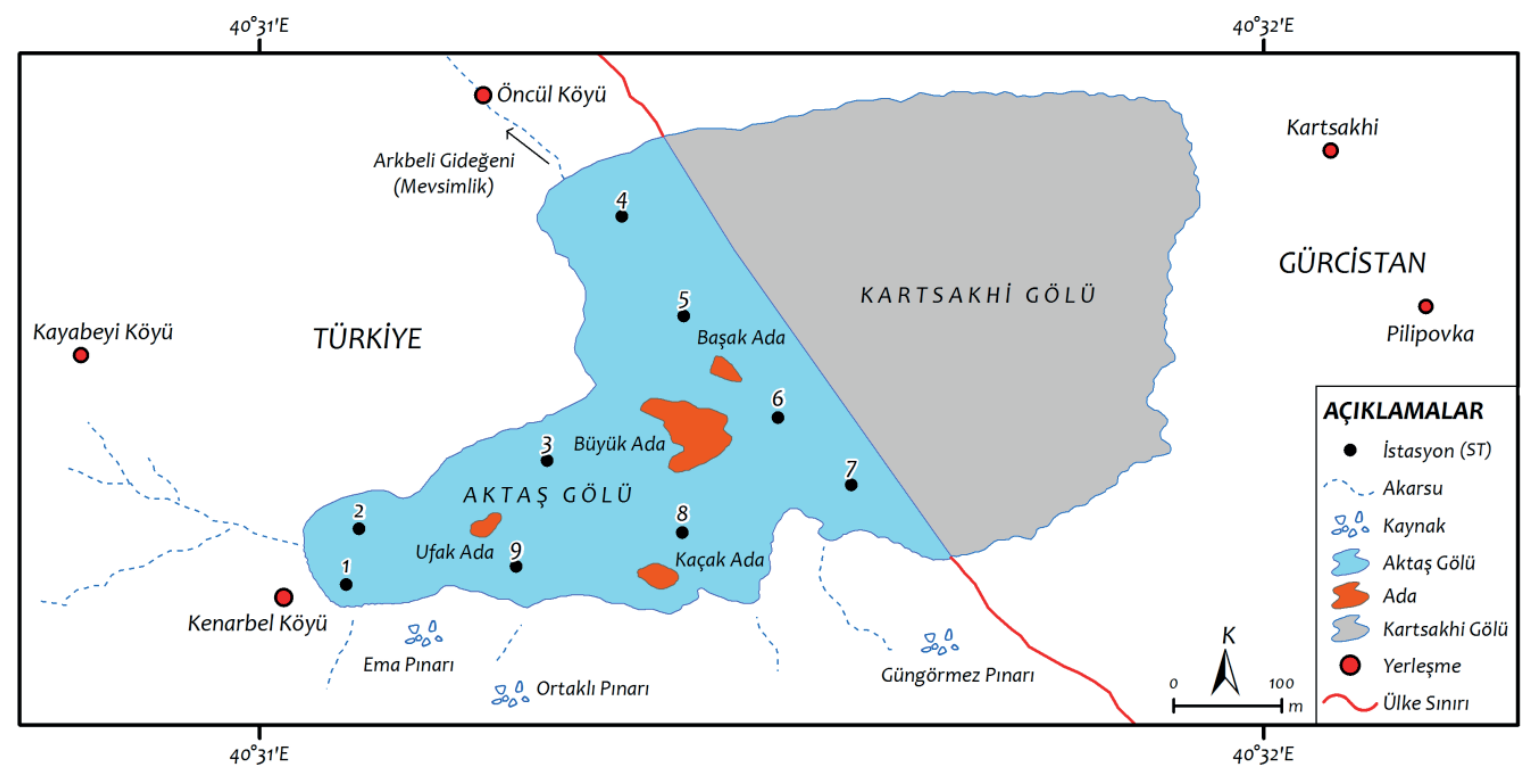

Şekil 2: Aktaş Gölü örnekleme noktaları.

Figure 2: Sampling stations in Aktaş Lake. 
- Pliyosen'e ait piroklastik kayaçlar yüzeylenmiş̧ir (Kırar, 1990). Bahsi geçen formasyonlar dışında göl çevresinde yüzeylenen Neojen'e ait marn ve konglomera gibi sedimanter kayaçlar ile lav ve tüfler diğer litolojik birimlerdir (Lahn, 1949; Güney, 2004). Göl havzasının volkanik kayaç formasyonları ile sinırlandırılması suların yoğun miktarda $\mathrm{Na}_{2} \mathrm{CO}_{3}$ (sodyum karbonat) içermesine neden olmuştur. $\mathrm{Bu}$ durum, volkanik kayaçlardaki sodyumlu feldspatların eriyerek göl sularına karışmasıyla açıklanmaktadır (Lahn, 1949). Ancak, ilkbaharda gölün debisinin artmasıyla Öncül köyü yakınlarındaki Arkbeli Deresi'nin göl sularını Kura Nehri'ne deşarj etmesi göl suyundaki $\mathrm{Na}_{2} \mathrm{CO}_{3}$ konsantrasyonunun azalmasına neden olmuştur (Lahn, 1949; Kırar, 1990; Doğanay ve Zaman, 2006).

Aktaş Gölü havzası ve yakın çevresinin jeomorfolojik oluşum ve gelişim süreçleri gölün tektonik kökenli olduğunu göstermektedir. Deniz seviyesinden 1798 metre yükseklikteki göl çanağı, güneybatı - kuzeydoğu doğrultulu iki eşik arasında bulunmaktadır (Lahn 1949; Koçman, 1979). Göl çanağı batıda 20 - 30 metre yüksekliğinde olan Kenarbel eşiği ile Çıldır Gölü havzasından, doğuda ise 50 metreye kadar yükselen Karzak eşiği ile ova ve plato sahasından ayrılmıştır (Lahn, 1948; 1949). Aktaş Gölü, Çıldır Gölü’nün de içerisinde yer aldığı Ardahan volkanik platosunun üzerinde yer almaktadır (İnandık, 1965). Göl çevresinin en önemli yükseltileri güneyde Türkiye - Gürcistan sınırında yer alan Göktepe Dağları (2780 m), Akbaba Dağı (3026 m) ve Çıldır Gölü’nün batısındaki Kısır Dağı'dır (3004 m). (Şekil 1).

Ardahan, Köppen - Geiger iklim sinıflandırmasına göre yüksek dağlık alanlarda görülen kışları soğuk nemli orta enlem yani karasal (D) iklim tipine ait Dfb alt sinıfina girmektedir (Öztürk, Gülden ve Aydın, 2017). Ardahan'da 1958-2019 arasında yıllık ortalama sıcaklık $3.6^{\circ} \mathrm{C}$, örneklemenin yapıldığ 2014 yılı ortalama sicaklık $5.7^{\circ} \mathrm{C}$ 'dir. 2014 yilı aylık ortalama sıcaklıklar 1958-2019 yılları arasındaki ortalamadan haziranda $1.1^{\circ} \mathrm{C}$, temmuzda $1.6^{\circ} \mathrm{C}$, ağustosta $2.5^{\circ} \mathrm{C}$ daha yüksektir. $\mathrm{Bu}$ veriler Türkiye'de özellikle yaz aylarındaki sıcaklık artışlarıyla uyumludur (Deniz ve Gönençgil, 2017). 2014 yılının ortalama sıcaklığ $\left.15.7^{\circ} \mathrm{C}\right)$, uzun yıllar ortalama sicaklıklardan $\left(3.6^{\circ} \mathrm{C}\right)$ $2.1^{\circ} \mathrm{C}$ daha yüksektir. Elde edilen bulgular 2014 yılının diğer yıllara göre daha sıcak geçtiğini göstermektedir.

Ardahan'da yıllık ortalama yağış 1958-2019 yılları arasında $555.6 \mathrm{~mm}$, örneklemenin yapıldığı 2014 yılında $655.9 \mathrm{~mm}$ 'dir. 1958-2019 yılları arasında aylık ortalama yağı̧̧ haziranda 94.43 $\mathrm{mm}$, temmuzda 70.61, ağustosta $62.30 \mathrm{~mm}$ 'dir. 2014 y1lı aylık ortalama yağış haziranda uzun yıllar ortalamasının $19.8 \mathrm{~mm}$ altına inerek $74.50 \mathrm{~mm}$, temmuzda uzun yıllar ortalamasının $61.79 \mathrm{~mm}$ üzerinde $132.40 \mathrm{~mm}$, ağustosta uzun yıllar ortalamasının $38.8 \mathrm{~mm}$ üzerinde, $101.10 \mathrm{~mm}$ seviyesindedir. Yağış verileri, örneklemenin yapıldığı 2014 yılının uzun yıllar ortalamaya göre daha yağışlı geçtiğini göstermektedir. Yağış miktarının haziranda uzun yıllar ortalamasının altında olması, temmuzda ve ağustosta uzun yıllar ortalamanın yaklaşık iki katı artması dikkat çekmektedir. Ardahan'da 1958-2019 arası yıllık toplam yağışta 149 mm'lik bir artış gerçekleşmiştir. Bu durum yağışlarda \%29'luk bir artışa karşılık gelir (Öztürk ve Kılıç, 2018).

Ardahan'da yıllık ortalama rüzgâr hızı $2.1 \mathrm{~m} / \mathrm{sn}$ olup, maksimum $32 \mathrm{~m} / \mathrm{sn}$ seviyesine ulaşmaktadır. Bölgede hâkim rüzgâr yönü batı - kuzeybatıdır. Son yıllarda yapılan çalışmalar Ardahan'da rüzgâr hızının azalmakta olduğunu göstermektedir (Öztürk ve Kılıç, 2018). Rüzgâr hızı göl suyunun iki ülke arasında dolaşması ve göl içinde dikey ölçekte karışmasını etkileyen önemli bir faktördür. Mevcut hâkim rüzgâr yönü gölün dalgalar ile Gürcistan kıyılarından kirletici taşınmasında doğrudan etkili olmadığını göstermektedir.

Göl, İran - Turan flora bölgesinde yer aldığı için saha flora türü çeşitliliği açısından çok zengin değildir. Gölün güneyinde küçük topluluklar halinde ağaç - çalı karışımı formasyonlar bulunmaktadır. Bunlar; Söğüt (Salix Caucasica ve Salix Caprea), çalı (Spiraea hypericifolia) ve Yabani Erik (Prunus spinosa) türleridir (Akgül, 2008).

Aktaş Gölü havzasında yapılan son araştırmalara göre; 1 tür sucul omurgasız hayvan sinıfinda yer alan Crustacea, 14 tür Insecta, 24 tür karasal omurgasız, 20 tür plankton, 6 tür balık, 2 tür Amphibia, 5 tür sürüngen, 107 tür kuş, 15 tür memeli yaşamaktadır (Kırpık, Altunoğlu ve Tanrıkulu, 2019). Sahanın flora ve fauna özellikleri birlikte değerlendirildiğinde bölgenin korunmaya değer ekolojik özelliklere sahip olan hassas bir alan olduğu anlaşılmaktadır.

Göl havzasında gerçekleştirilen arazi çalışmalarında bölgenin ekolojik yapısını kısa vadede bozacak düzeyde yoğun antropojenik faaliyetlere rastlanmamıştır. Göle yakın alanlarda sürdürülen yem bitkileri ve tahıl üretimi en önemli antropojenik faaliyettir. Kenarbel, Kayabeyi ve Öncül köyleri göl yakınında yer alan yerleşmelerdir (Şekil 2). Ancak, bu yerleşmelerde nüfus ve arazi kullanımı baskısı yoktur. Göl yakınında yer alan karayolu günümüzde çok yoğun değildir. Bu nedenle gölü tehdit eden bir antropojenik risk kaynağı yoktur. Aktaş Gölü'nde gerçekleştirilen toksik ve ekolojik risk araştırmalarında risk 
tespit edilmemesi sahanın doğal ortam özelliklerinin antropojenik etkiler ile bozulmadığını göstermektedir (Kükrer, 2017).

\subsection{Yöntem}

Çalışma kapsamında öncelikle keşif amaçlı arazi çalışması düzenlenmiştir. Arazi çalışmasında su kalitesine etki edebilecek muhtemel unsurlar belirlenerek bu unsurların konumu ve mekânsal analiz aralığına uygunluğa göre örnekleme noktaları belirlenmiştir. Ardından yüzey suyu örneklemesi için Türkiye sınırlarında geçerli gerekli izinler alınarak yeterli iş güvenliği tedbirleri ile örnekleme çalışmasına geçilmiştir. Gölün bir kısmı Gürcistan sınırında yer aldığından dolayı araştırma izinleri konusunda sorunlar yaşanmıştır. Bu nedenle, Aktaş Gölü'nde Türkiye sınırları içerisinden seçilen 9 örnekleme noktasından 2014 yılı haziran, temmuz, ağustos aylarında yüzey suyu örnekleri alınmıştır (Şekil 2). Su örnekleri polietilen şişelere konularak laboratuvara taşınmıştır. Örnekler üzerinde sıcaklık, oksijen, $\mathrm{pH}$, nitrat $\left(\mathrm{NO}_{3}-\mathrm{N}\right)$, nitrit $\left(\mathrm{NO}_{2}-\mathrm{N}\right)$, amonyum $\left(\mathrm{NO}_{4}-\mathrm{N}\right)$ ve fosfat $\left(\mathrm{PO}_{4}^{-3}-\mathrm{P}\right)$ ölçümleri gerçekleştirilmiştir. Sıcaklık ve $\mathrm{pH}$ ölçümleri Termo Scientific marka $\mathrm{pH}$ metre ile, doymuş oksijen ölçümü (DO) ise Winkler metodu ile yapılmıştır. Nutrient konsantrasyonu analizlerinde $\mathrm{NO}_{4}-\mathrm{N}$ ve $\mathrm{PO}_{4}{ }^{-3}-\mathrm{P}$ için (Strickland ve Parsons, 1972), $\mathrm{NO}_{2}-\mathrm{N}$ ve $\mathrm{NO}_{3}-\mathrm{N}$ için (Wood, 1975) tarafından geliştirilen yöntemler kullanılmıştır. Nutrient birimleri $\mathrm{mg} / \mathrm{L}$ olarak hesaplanmış, kullanılan yöntemlerin hassasiyetleri Tablo 1'de sunulmuştur. Analizlerden elde edilen bulgular Arc - Map 10.7 yazilıminda yer alan kriging enterpolasyon metodu ile mekânsal analiz haritalarına dönüştürülmüştür.

Tablo 1: Analizlerin hassasiyet ve ölçüm aralıkları. Table 1: Analyzes sensitivity and measurement ranges.

\begin{tabular}{lll}
\hline Değişken & Hassasiyet & Saptama Aralığı \\
\hline $\mathrm{NH}_{2}-\mathrm{N}$ & $\pm 0.20 \mu \mathrm{g}$ afN $/ \mathrm{L}(1.00 \mu \mathrm{g}$ afN $/ \mathrm{L})(1.70 \mathrm{~cm}$ hücre ile $)$ & $0.10-45.00 \mu \mathrm{g} / \mathrm{L}$ \\
$\mathrm{NH}_{3}-\mathrm{N}$ & $\pm 0.20 \mu \mathrm{g}$ afN $/ \mathrm{L}(1.00 \mu \mathrm{g}$ afN $/ \mathrm{L})(1.70 \mathrm{~cm}$ hücre ile) & $0.10-2.50 \mu \mathrm{g} / \mathrm{L}$ \\
$\mathrm{NH}_{4}-\mathrm{N}$ & $\pm 0.70 \mu \mathrm{g} \mathrm{afN} / \mathrm{L}(1.00 \mu \mathrm{g}$ afN $/ \mathrm{L})(1.70 \mathrm{~cm}$ hücre ile $)$ & $0.20-10.00 \mu \mathrm{g} / \mathrm{L}$ \\
$\mathrm{PO}_{4}-\mathrm{P}$ & $0.03 \mu \mathrm{P} / \mathrm{L}(3.00 \mu \mathrm{g} \mathrm{N} / \mathrm{L})(1.70 \mathrm{~cm}$ hücre ile $)$ & $0.05-5.00 \mu \mathrm{g} / \mathrm{L}$ \\
$\mathrm{DO}$ & $\pm 0.30 \mathrm{mg} / \mathrm{L}\left( \pm 20^{\circ} \mathrm{C}\right)$ & \\
\hline
\end{tabular}

\subsection{Amaç ve Kapsam}

Bu çalışmanın amacı; Aktaş Gölü yüzey sularında sıcaklık, $\mathrm{pH}$, çözünmüş oksijen ve nutrient konsantrasyonları gibi ekolojik özelliklerin zamansal ve mekânsal değişimlerini CBS ve çok değişkenli istatiksel analizlerle tespit etmektir. Çalışma kapsamında; gölün yüzey sularının ekolojik özellikleri resmi kurumların belirlediği sınır değerler ile karşılaştırılarak su kalitesi ve ekolojik durum hakkında değerlendirmeler yapılmış, tespit edilen sorunlara çözüm önerileri sunulmuştur.

\section{BULGULAR VE TARTIŞMA}

\subsection{Göl suyu sıcaklığının zamansal ve mekânsal değişimi}

Ardahan'da 2014 yılı aylık ortalama hava sicaklığı haziranda $13.8^{\circ} \mathrm{C}$, temmuzda $17^{\circ} \mathrm{C}$, ağustosta $18.3^{\circ} \mathrm{C}$ 'dir (MGM, 2014). Ölçüm yapılan üç ayda ortalama hava sıcaklığı $13.8^{\circ} \mathrm{C}-18.3^{\circ} \mathrm{C}$, göl suyunun sicaklığ 1 ise $15^{\circ} \mathrm{C}-22.5^{\circ} \mathrm{C}$ arasında tespit edilmiş̧tir. Göl suyunun ortalama sıcaklığ $19.6 \pm 0.5^{\circ} \mathrm{C}$ olarak hesaplanmıştır. Haziran'da maksimum yüzey suyu sıcaklığı ST $4^{\prime}$ 'te $\left(17.3^{\circ} \mathrm{C}\right)$, minimum sıcaklık $\left(15^{\circ} \mathrm{C}\right)$ ise ST $8^{\prime}$ de tespit edilmiștir. Temmuz'da maksimum $\left(22.1^{\circ} \mathrm{C}\right)$ sicaklık ST $7^{\prime}$ de, minimum sıcaklık ST 4 'te $\left(20.5^{\circ} \mathrm{C}\right)$ tespit edilmiştir. Ağustos'ta ST 8'de maksimum $\left(22.5^{\circ} \mathrm{C}\right)$ olan su sicaklığ $1 \mathrm{ST} 5^{\prime}$ te $\left(21.1^{\circ} \mathrm{C}\right)$ minimuma düşmektedir (Şekil 3). Su sıcaklığının mekânsal dağılışı incelendiğinde gölde bütün aylarda güney - kuzey doğrultusunda değişimler yaşandığı tespit edilmiştir (Şekil 3). Gölün güneyinde gölü besleyen su kaynakları vardır. Kuzeyde ST 4 yakınında gölü Kura Nehri'ne bağlayan Arkbeli gideğeni bulunmaktadır (Lahn, 1949; Kırar, 1990). Bu durum, göl suyu sıcaklığının değişiminde gideğen ve kaynakların etkili olabileceğini göstermektedir. Bahsi geçen faktörler dışında su sıcaklı̆̆ 1 üzerinde etkili olabilecek düzeyde sürekli akarsu ya da güçlü mevsimsel yan kol bulunmamaktadır.

\section{2. pH'ın zamansal ve mekânsal değişimi}

Göl suyunun $\mathrm{pH}$ konsantrasyonu haziran, temmuz ve ağustosta 8.67-9.63 arasında değişmiştir. Minimum pH ağustosta ST 5'te tespit edilirken, maksimum $\mathrm{pH}$ ise haziranda aynı örnekleme noktasında ölçülmüştür. $\mathrm{pH}$ haziranda ST 5 'te maksimum (9.63), ST 1'de minimum (9.20) seviyede tespit edilmiştir. Temmuz' da maksimum (9.31) pH ST 9'da, minimum pH (8.96) ST 1'de tespit edilmiștir. pH ağustosta ST 3'te maksimum (8.93), ST 5'te (8.67) minimumdur. $\mathrm{pH}$ konsantrasyonunun haziran - ağustos ayları arasında düşüş eğiliminde olduğu dikkat çekmektedir (Şekil 3). Şener, vd., tarafından Eğirdir Gölü'nde yapılan çalışmada pH konsantrasyonunun diğer göllerden yüksek olması, bölgedeki karbonatlı kayaçların varlığına bağlanmıştır (Şener, vd., 2014). Aktaş Gölü sularının sodalı oluşu sebebiyle pH değerleri Eğirdir Gölü ile benzerlik göstermektedir. Aktaş Gölü çevresinde karbonatlı kayaç formasyonu bulunmamaktadır. Ancak, göl suyunun sodalı olmasının ve $\mathrm{pH}$ konsantrasyonunun yüksek olmasının muhtemel nedeni litolojik özelliklerdir (Şimşek, 2019). Çünkü, Aktaş Gölü ve çevresi volkanik kayaç formasyonlarıyla kaplıdır (Lahn, 1949). Mekânsal analiz verilerine göre $\mathrm{pH}$ konsantrasyonunun örnekleme yapılan bütün 

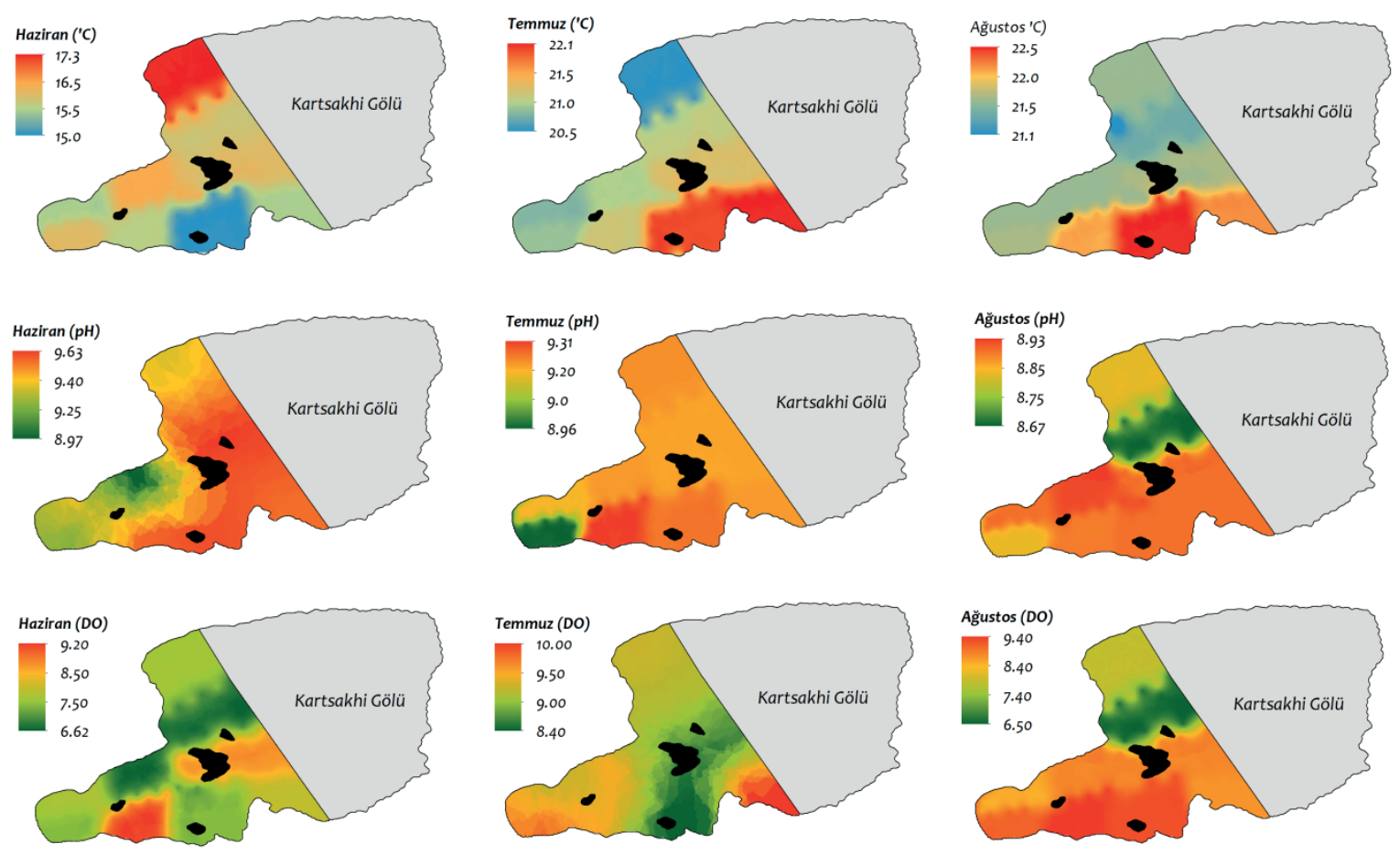

Şekil 3: Sıcaklık, pH ve DO'nun zamansal ve mekânsal değişimi.

Figure 3: Temporal and spatial variation of Temperature, $\mathrm{pH}$ and DO.

aylarda gölün güneyindeki pınarlara yakın örnekleme noktalarında yüksektir. $\mathrm{Bu}$ durum pınarların göldeki $\mathrm{pH}$ konsantrasyonunun değişiminde etkili olduğunu göstermektedir.

\section{3 Çözünmüş oksijenin (DO) zamansal ve mekânsal değişimi}

Göl suyunda minimum DO konsantrasyonu ağustosta (6.5 $\mathrm{mg} / \mathrm{L})$, maksimum konsantrasyon ise temmuzda $(10 \mathrm{mg} / \mathrm{L})$ tespit edilmiştir. Ortalama DO konsantrasyonu $8.44 \pm 0.19 \mathrm{mg} / \mathrm{L}$ 'dir. DO haziranda ST 9'da maksimum (9.2 mg/L), ST 3 ve ST 4'te minimum konsantrasyondadır $(6.6 \mathrm{mg} / \mathrm{L})$. Temmuz'da maksimum konsantrasyon (10 mg/L) ST 7'de, minimum konsantrasyon $(8.4 \mathrm{mg} / \mathrm{L}) \mathrm{ST} 8$ 'de tespit edilmiştir. Ağustos'ta ise ST 9'da maksimum (9.4 mg/L), ST 5'te ise minimum (6.59 $\mathrm{mg} / \mathrm{L}$ ) konsantrasyon tespit edilmiştir (Şekil 3). T.C. Tarım ve Orman Bakanlığı'nın Yerüstü Su Kalitesi Yönetmeliği’nde verilen kalite standartlarına göre DO konsantrasyonu I. sınıf (çok iyi) ve II. sınıf (iyi) arasında değişiklik göstermektedir. Sudaki DO konsantrasyonunun gazların çözünürlüğüne bağlı olarak sıcaklıkla ters orantılı şekilde değişmesi beklenirken bu durum Aktaş Gölü yüzey sularında gerçekleşmemiştir. Bahsi geçen durum gölde yaz aylarında artan fotosentez faaliyetlerinin bir sonucu olabilir. DO’nun mekânsal dağılışı incelendiğinde maksimum konsantrasyonun ağustosta pınarların yer aldığ güney kesimlerde tespit edildiği dikkat çekmektedir. Temmuz ayında Kaçak Ada çevresi hariç tutulduğunda DO konsantrasyonu yine gölün güney kıyılarında yüksektir. Bu durum, göle deşarj olan pınarların DO konsantrasyonunun artmasını sağladığını göstermektedir.

\subsection{Nitrit'in $\left(\mathrm{NO}_{2}-\mathrm{N}\right)$ zamansal ve mekânsal değişimi}

Aktaş Gölü yüzey sularında minimum $\mathrm{NO}_{2}-\mathrm{N}$ konsantrasyonu $0.002 \mathrm{mg} / \mathrm{L}$ ile ağustosta ST 3'te, maksimum konsantrasyon ise $0.081 \mathrm{mg} / \mathrm{L}$ olarak haziranda ST 1' de tespit edilmiştir. $\mathrm{NO}_{2}-\mathrm{N}$ 'in üç aylık ortalama konsantrasyonu $0.015 \pm 0.003 \mathrm{mg} / \mathrm{L}$ olarak belirlenmiştir. $\mathrm{NO}_{2}-\mathrm{N}$ konsantrasyonu haziranda ST 1'de maksimum (0.081), ST 3'te minimum (0.010) seviyededir. Temmuz'da maksimum konsantrasyon (0.057) ST 6'da, minimum konsantrasyon ise (0.003) ST 3'te tespit edilmiştir. $\mathrm{NO}_{2}-\mathrm{N}$ konsantrasyonu ağustosta ST 7, ST 8. ve ST 9'da maksimum (0.006), ST 3'te minimum (0.002) olarak belirlenmiştir. $\mathrm{NO}_{2}-\mathrm{N}$ konsantrasyonu haziran - ağustos arasında azalma eğilimindedir (Şekil 4). Mekânsal analiz verilerine göre $\mathrm{NO}_{2}-\mathrm{N}$ konsantrasyonunun ağustosta gölü besleyen pınarların olduğu güney kesimde ve Arkbeli gideğeninin yer aldığı kuzey kesimde maksimum konsantrasyona çıkmaktadır. Bunun yanında, temmuzda Büyük Ada'nın doğusunda Gürcistan sınırında tespit edilen maksimum $\mathrm{NO}_{2}-\mathrm{N}$ konsantrasyonu Gürcistan sınırında gerçekleşen antropojenik etkilerin Aktaş 

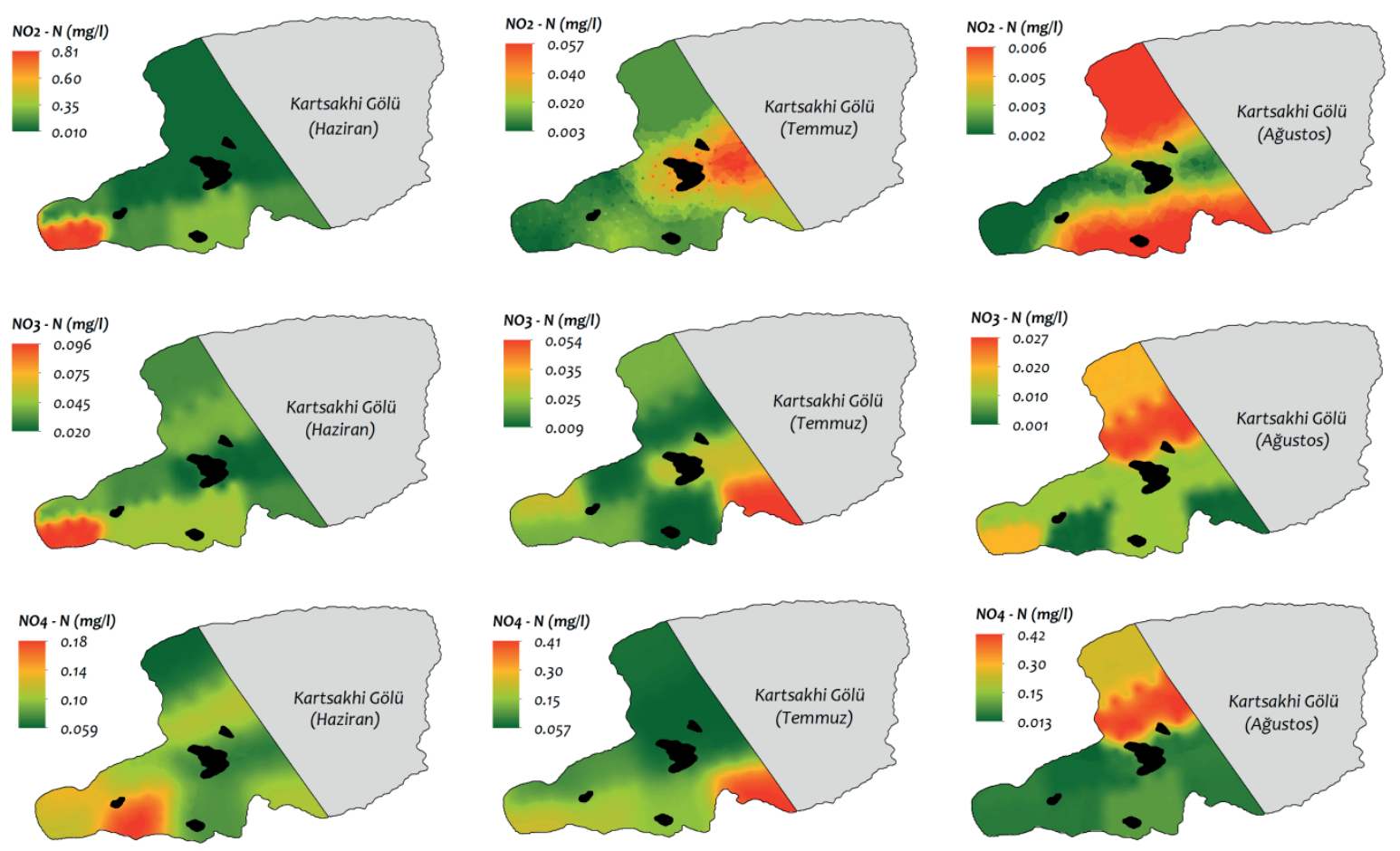

Şekil 4: $\mathrm{NO}_{2}-\mathrm{N}, \mathrm{NO}_{3}-\mathrm{N}, \mathrm{NO}_{4}$ - N'in zamansal ve mekânsal değişimi.

Figure 4: Temporal and spatial variation of $\mathrm{NO}_{2}-\mathrm{N}, \mathrm{NO}_{3}-\mathrm{N}, \mathrm{NO}_{4}-\mathrm{N}$.

Gölü’nün ekolojik özelliklerini olumsuz etkileyebileceğinin önemli bir göstergesidir.

\subsection{Nitrat'ın $\left(\mathrm{NO}_{3}-\mathrm{N}\right)$ zamansal ve mekânsal değişimi}

$\mathrm{NO}_{3}$-N konsantrasyonu üç aylık süreçte 0.001 ile $0.096 \mathrm{mg} / \mathrm{L}$ arasında değişmiş̧ir. Minimum konsantrasyon ağustosta ST 7'de, maksimum konsantrasyon ise haziranda ST 1'de tespit edilmiştir. Haziran, temmuz ve ağustos ayları ortalaması $0.025 \pm 0.003 \mathrm{mg} /$ L'dir. Haziran'da maksimum konsantrasyon (0.096) ST 1, minimum konsantrasyon (0.020) ST 6'da tespit edilmiştir. Temmuz'da maksimum konsantrasyon (0.054) ST 7'de, minimum konsantrasyon ise (0.011) ST 5'te tespit edilmiştir. Ağustos'ta ST 5 'te maksimum (0.027), ST 7'de minimum (0.001) konsantrasyon belirlenmiştir (Şekil 4). Mekânsal dağllişa göre $\mathrm{NO}_{3}-\mathrm{N}$ trendlerinin $\mathrm{NO}_{2}-\mathrm{N}$ ile benzeştiği ve haziran, temmuz, ağustos aylarında düzenli bir azalma eğilimi içinde olduğu tespit edilmiştir. Göl sularının $\mathrm{NO}_{3}-\mathrm{N}$ konsantrasyonu T.C. Tarım ve Orman Bakanlığ kriterlerine göre I. sınıfta (çok iyi) yer almaktadır.

\subsection{Amonyum'un $\left(\mathrm{NH}_{4}-\mathrm{N}\right)$ zamansal ve mekânsal değişimi}

$\mathrm{NH}_{4}-\mathrm{N}$ konsantrasyonu $\quad 0.013-0.42 \quad \mathrm{mg} / \mathrm{L}$ arasinda değişmektedir. Minimum $\mathrm{NH}_{4}-\mathrm{N}$ konsantrasyonu ağustosta $\mathrm{ST}$ 3'te belirlenirken, maksimum konsantrasyon ise aynı ayda ST 5'te tespit edilmiştir. $\mathrm{NH}_{4}-\mathrm{N}$ konsantrasyonu haziranda Ufak Ada'nın güneyinde ST 9'da maksimum, ST 4'te ise minimumdur. Temmuz'da maksimum konsantrasyon ST 7'de, minimum konsantrasyon ST 5'te tespit edilmiştir. Ağustos'ta ST 5'te maksimum, ST 3'te minimum konsantrasyon tespit edilmiştir (Şekil 4). $\mathrm{NH}_{4}-\mathrm{N}$ konsantrasyonunun temmuzda haziran ayına kıyasla bir artış yaptığı ve ağustosta tekrar haziran seviyesine gerilediği görülmektedir. Gölün yüzey sularının $\mathrm{NH}_{4}-\mathrm{N}$ konsantrasyonu T.C. Tarım ve Orman Bakanlığı standartlarına göre I. sınıf - II. sınıf arasında değişkenlik göstermektedir. Mekânsal analizlere göre $\mathrm{NH}_{4}-\mathrm{N}$ konsantrasyonunun haziran ve temmuzda gölün güney kıyılarında, ağustosta kuzey kıyılarında arttığı dikkat çekmektedir. Bu durumda gölü besleyen pınarlar ve Arkbeli gideğeninin $\mathrm{NH}_{4}-\mathrm{N}$ 'in mekânsal dağılışında belirleyici olduğu söylenebilir.

\subsection{Fosfat'ın ( $\left.\mathrm{PO}_{4}-\mathrm{P}\right)$ zamansal ve mekânsal değişimi}

Minimum $\mathrm{PO}_{4}-\mathrm{P}$ konsantrasyonu $0.111 \mathrm{mg} / \mathrm{L}$ ile haziranda ST 6'da, maksimum $\mathrm{PO}_{4}-\mathrm{P}$ konsantrasyonu ise $0.256 \mathrm{mg} / \mathrm{L}$ ile ağustosta ST 5 'te tespit edilmiştir. $\mathrm{PO}_{4}$-P'ün üç aylık ortalama konsantrasyonu ise $0.152 \mathrm{mg} / \mathrm{L}$ olarak tespit edilmiştir. $\mathrm{PO}_{4}-\mathrm{P}$ için maksimum konsantrasyon haziranda ST $1(0.248 \mathrm{mg} / \mathrm{L})$, temmuzda ST $4(0.194 \mathrm{mg} / \mathrm{L})$, ağustosta ST 5 'te $(0.256 \mathrm{mg} / \mathrm{L})$ tespit edilmiştir. Minimum konsantrasyon ise haziranda ST 6 

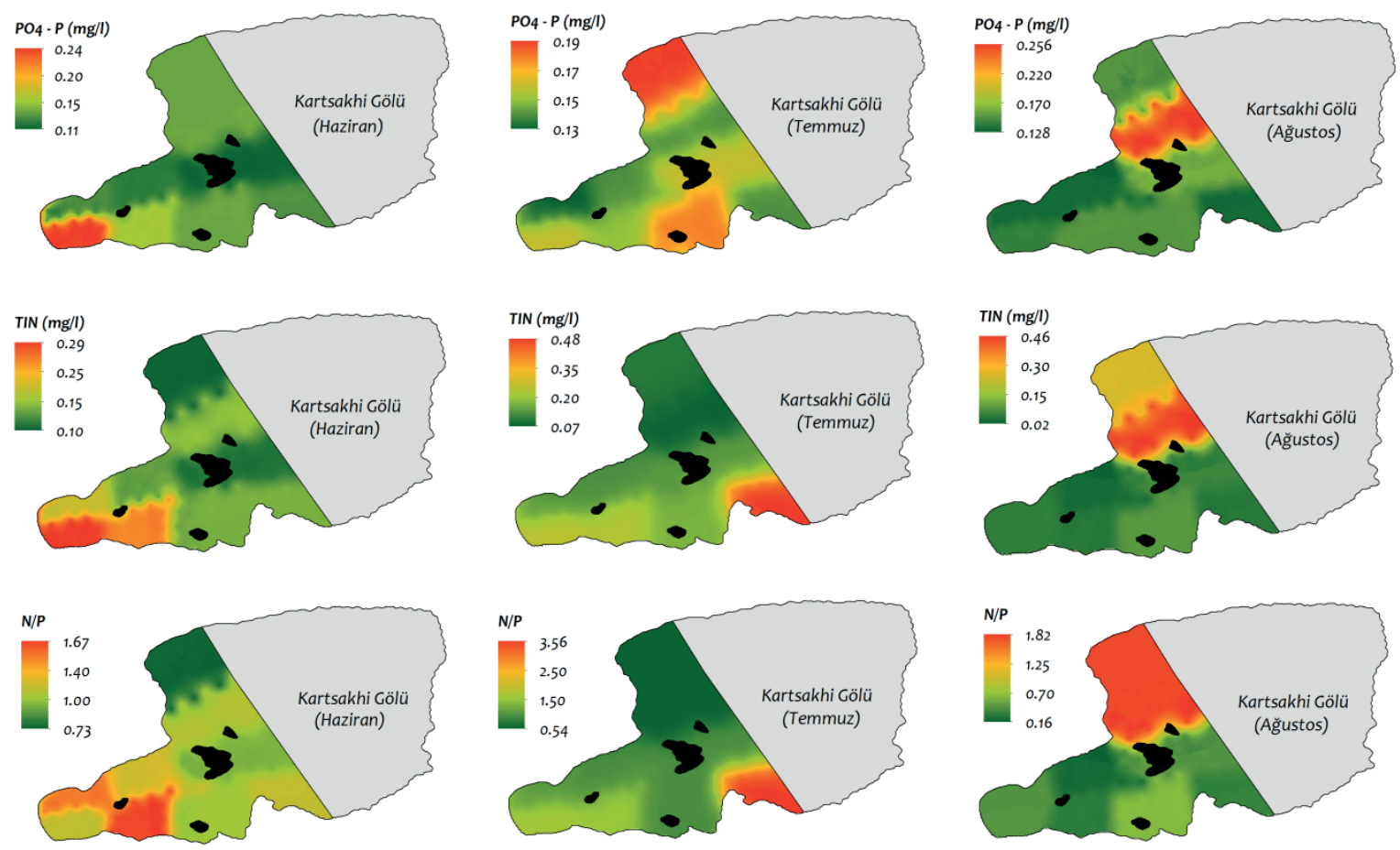

Şekil 5: $\mathrm{PO}_{4}-\mathrm{P}$, TIN ve N/P'nin zamansal ve mekânsal değişimi.

Figure 5: Temporal and spatial variation $\mathrm{PO}_{4}-\mathrm{P}, \mathrm{TIN}$ ve N/P.

(0.111 mg/L), temmuzda ST 2 (0.132), ağustosta ST 7'de (0.128 $\mathrm{mg} / \mathrm{L}$ ) tespit edilmiştir (Şekil 5). $\mathrm{PO}_{4}$-P'nin gölün yüzey sularında yaz ayları boyunca azotlu nutrientlere kıyasla daha yüksek konsantrasyonda bulunduğu tespit edilmiştir. T.C. Tarım ve Orman Bakanlığ 1 kriterlerine göre gölün $\mathrm{PO}_{4}$-Pkonsantrasyonu II. sınıf (iyi) ve III. sınıf (orta kalite) arasında değiş̧mektedir.

\subsection{Toplam inorganik Azotun (TIN) zamansal ve mekânsal değişimi}

Ölçümü yapılan üç azot formunun toplamını ifade eden TIN'in zamansal ve mekânsal değişimi incelendiğinde; temmuz ve ağustosta önemli artışların olduğu görülmektedir. TIN maksimum konsantrasyona $(0.489 \mathrm{mg} / \mathrm{L})$ temmuzda ST 7'de, ağustosta $(0.461 \mathrm{mg} / \mathrm{L}) \mathrm{ST} 5$ 'te ulaşmıştır. Ağustos'ta bir pik olmasına rağmen TIN'in diğer aylara göre düşük seyrettiği tespit edilmiştir. TIN için minimum konsantrasyon $0.101 \mathrm{mg} / \mathrm{L}$ ile haziranda ST 4'te, $0.077 \mathrm{mg} / \mathrm{L}$ ile temmuzda ST 5'te, 0.024 $\mathrm{mg} / \mathrm{L}$ ile ağustosta ST 3'te belirlenmiştir. Ağustos'ta diğer örnekleme noktalarındaki düşük konsantrasyona rağmen ST 4 ve ST 5'teki artış bu noktalara yakın kısımlardan madde girişi olabileceğini düşündürmektedir (Şekil 5). Benzer şekilde $\mathrm{PO}_{4}$ P'de ST 5 'te bir maksimum izlenmiş olması evsel atıkları içeren bir kaynağ 1 işaret ediyor olabilir. Ancak ST 5 çevresinde Türkiye sınırlarında karadan herhangi bir su deşarjı gerçekleşmemektedir.

\subsection{N/P oranının zamansal ve mekânsal değişimi}

N/P oranı sudaki azot ve fosfor oranını ifade etmektedir. Maksimum N/P oran 3.57 ile temmuzda belirlenirken, minimum oran 0.16 ile ağustosta belirlenmiştir (Şekil 5). Nutrientlerin aynı ayda bile örnekleme noktaları arasında gösterdiği farklı mekansal dağılımlar N/P oranlarını da etkilemiştir. Aktaş Gölü N/P oranları Redfield oranı olarak kabul edilen N:P 16:1 oranının altında kalmıştır. Denizlerdeki alg hücrelerinde tespit edilen bu oran genellikle deniz ve okyanuslardaki sınırlayıcı elementlerin belirlenmesi amacıyla kullanılmaktadır. Ancak N:P 16:1 oranı tatlı sularda da kullanılabilir (Teubner ve Dokulil, 2002). Aktaş Gölü'nün N/P oranları incelendiğinde; yaz ayları boyunca azotun sinırlayıcı olduğu görülmektedir. $\mathrm{PO}_{4}-\mathrm{P}$ konsantrasyonunun yaz ayları boyunca değişmeden belli seviyelerde kalması ve buna karşın TIN konsantrasyonunun aylar arasında farklılık göstermesi bu durumu doğrulamaktadır.

Aktaş Gölü nutrient konsantrasyonu bulgularının diğer göllerde yapılan çalışma bulgularıyla karşılaştırılması Tablo 2'de sunulmuştur. Aktaş Gölü $\mathrm{NO}_{2}-\mathrm{N}$ konsantrasyonu minimum değerlere göre Beyşehir Gölü'nden fazla (Dididen vd., 2013), Gölcük Gölü (Mis ve Ustaoğlu 2009), Tortum Gölü (Kıvrak ve Gürbüz 2006), Karagöl(Mutlu vd., 2013) ve Çömlekçi Deresi’nden azdır (Ustaoğlu 2020). $\mathrm{NO}_{2}$-N maksimum konsantrasyona göre 
Tablo 2: Aktaş Gölü su kalitesi değerlerinin Türkiye'nin farklı bölgelerindeki göllerle karşılaştırılması.

Table 2: Comparison of value Aktaş Lake water quality of lakes in different regions of Turkey.

\begin{tabular}{lccccl}
\hline Lokasyon & $\mathbf{N H}_{\mathbf{2}}-\mathbf{N}$ & $\mathbf{N H}_{\mathbf{3}} \mathbf{- N}$ & $\mathbf{N H}_{\mathbf{4}} \mathbf{- N}$ & $\mathbf{P O}_{\mathbf{4}}-\mathbf{P}$ & Kaynak \\
\hline Aktaş $(\mathrm{mg} / \mathrm{L})$ & $0.002-0.081$ & $0.001-0.096$ & $0.013-0.428$ & $0.111-0.256$ & Bu çalışma \\
Aktaş $(\mu \mathrm{g} / \mathrm{L})$ & - & $101-234$ & $12.2-83.8$ & $18.3-34.0$ & (Özbay ve Kılınç, 2008) \\
Beyşehir $(\mathrm{mg} / \mathrm{L})$ & $<0.02$ & $<0.5$ & $0.07-0.13$ & $<0.2-0.2$ & (Didinen vd., 2013) \\
Gölcük $(\mu \mathrm{g} / \mathrm{L})$ & $0.02-7.03$ & $* 0-295.56$ & $20.20-200.60$ & $9.60-59.52$ & (Mis ve Ustaoğlu, 2009) \\
Tortum $(\mathrm{mg} / \mathrm{L})$ & $0.003-0.012$ & $0.3-0.65$ & $0.07-0.25$ & $0.015-0.075$ & (Kıvrak ve Gürbüz, 2006) \\
Karagöl $(\mathrm{mg} / \mathrm{L})$ & $* 0-0.02$ & $0.48-5.96$ & $0.01-0.51$ & $0.12-0.36$ & Mutlu vd., 2013 \\
Tecer Gölü $(\mathrm{mg} / \mathrm{L})$ & $0.0005-0.0103$ & $2.09-7.15$ & $0.0004-0.0247$ & $0.55-0.221$ & Mutlu vd., 2018 \\
Bektaş Göleti $(\mathrm{mg} / \mathrm{L})$ & $0-0.004$ & $0.52-4.46$ & $0-0.002$ & $0.19-0.688$ & Uncumusaoğlu, 2018 \\
Çömlekçi Deresi & $0.001-0.027$ & $0.03-1.25$ & - & - & Ustaoğlu, 2020 \\
\hline
\end{tabular}

0* ölçüm limiti altında

Beyş̧ehir Gölü, Karagöl, Bektaş Göleti (Uncumusaoğlu, 2018), Çömlekçi Deresi ve Tortum Gölü’nden yüksek, Gölcük Gölü'nden düşüktür. $\mathrm{NO}_{3}$-N konsantrasyonu minimum değerlere göre Gölcük Gölü hariç düşüktür. Maksimum konsantrasyona göre değerlendirildiğinde $\mathrm{NO}_{3}-\mathrm{N}$ konsantrasyonu bütün göllerden düşüktür. $\mathrm{NH}_{4}-\mathrm{N}$ minimum konsantrasyona göre Gölcük Gölü'nden düşük, diğer sulak alanlardan yüksektir. $\mathrm{NH}_{4}-\mathrm{N}$ maksimum konsantrasyona göre Beyşehir Gölü, Karagöl ve Tortum Gölü’nden yüksek, diğer göllerden düşüktür. $\mathrm{PO}_{4}-\mathrm{P}$ minimum konsantrasyona göre bütün sulak alanlardan düşük; maksimum konsantrasyona göre Aktaş Gölü'nde 2004 - 2005 yılında tespit edilen değerden, Gölcük Gölü, Beyşehir Gölü ve Karagöl'den düşük, diğer sulak alanlardan yüksektir. Aktaş Gölü'nde Özbay ve Kılıç (2008) tarafindan yapılan çalışmanın bulgularıyla karşılaştırıldığında, $\mathrm{PO}_{4}-\mathrm{P}$ ve $\mathrm{NH}_{4}-\mathrm{N}$ değerlerindeki artış dikkat çekici düzeydedir. Bu durum göl çevresindeki yerleşim yerlerindeki evsel atıkların göle ulaşarak su kalitesine olumsuz etki yaptığını göstermektedir. Ayrıca büyük sürüler halinde göle getirilip su ihtiyaçları karşılanan büyükbaş hayvanların atıkları da sahilde önemli bir birikime sebep olmaktadır.

\subsection{0. Çok değişkenli istatistiksel analizler}

Değişkenlere uygulanan spearman korelasyon testinin $(\mathrm{p}<$ $0.05)$ sonuçlarına göre $\mathrm{NH}_{2}-\mathrm{N}-\mathrm{NH}_{3}-\mathrm{N}$ ve $\mathrm{NH}_{4}-\mathrm{N}$ arasında pozitif korelasyon bulunduğu, $\mathrm{PO}_{4}-\mathrm{P}$ 'nin ise azotlu nutrientlerle ilişkili olmadığı tespit edilmiştir. N/P ile TIN arasındaki yüksek pozitif korelasyon N/P oranındaki değişimlerin büyük oranda azotlu nutrientlerdeki değişimlerden kaynaklandığını ortaya koymaktadır (Tablo 3).

Değişkenlerin kümelenişini tespit etmek amacıyla yapılan Cluster analizinde $\mathrm{NH}_{2}-\mathrm{N}$ ve $\mathrm{NH}_{3}-\mathrm{N}$ 'in birbiriyle yakın ilişki içinde olduğu, $\mathrm{N} / \mathrm{P}$ oranının ise $\mathrm{PO}_{4}-\mathrm{P}$ konsantrasyonundaki değişimlerden etkilendiği görünmektedir. $\mathrm{PO}_{4}-\mathrm{P}$ ve diğer nutrient değişkenleri arasında ilişkisi tespit edilmemiştir (Şekil 6).

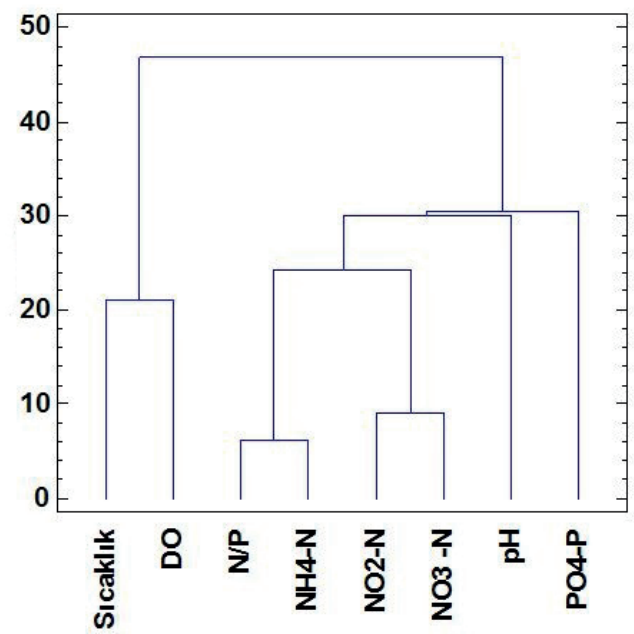

Şekil 6: Cluster analizi dendogramı. Figure 6: Cluster analysis dendogram.

Tablo 3: Spearman korelasyon matrisi.

Table 3: Spearman correlation matrix.

\begin{tabular}{|c|c|c|c|c|c|c|c|c|c|}
\hline & Sıcaklık & pH & DO & $\mathrm{NH}_{2}-\mathrm{N}$ & $\mathrm{NH}_{3}-\mathrm{N}$ & $\mathrm{NH}_{4}-\mathrm{N}$ & $\mathrm{PO}_{4}-\mathrm{P}$ & TIN & N/P \\
\hline \multicolumn{10}{|c|}{ Sıcaklık } \\
\hline pH & -0.6781 & & & & & & & & \\
\hline DO & 0.4557 & -0.1353 & & & & & & & \\
\hline $\mathbf{N H}_{2}-\mathbf{N}$ & -0.4923 & 0.6876 & -0.2612 & & & & & & \\
\hline $\mathbf{N H}_{3}-\mathbf{N}$ & -0.6322 & 0.5067 & -0.3681 & 0.7390 & & & & & \\
\hline $\mathbf{N H}_{4}-\mathbf{N}$ & -0.2612 & 0.2246 & -0.0256 & 0.2829 & 0.5247 & & & & \\
\hline $\mathrm{PO}_{4}-\mathrm{P}$ & 0.1645 & -0.1822 & 0.0956 & -0.0543 & 0.0318 & 0.2903 & & & \\
\hline TIN & -0.3271 & 0.2746 & -0.1622 & 0.5022 & 0.7176 & 0.9334 & 0.3538 & & \\
\hline N/P & -0.3767 & 0.2477 & -0.1554 & 0.4559 & 0.7280 & 0.9218 & 0.1468 & 0.9490 & \\
\hline
\end{tabular}


Faktör analizinde tespit edilen iki faktör verilerin \%67.6'sını açıklamaktadır. Birinci faktör verilerin \%42.6'sını açıklarken, ağırlıklı olarak $\mathrm{NH}_{2}-\mathrm{N}, \mathrm{NH}_{3}-\mathrm{N}$, sicaklık, $\mathrm{pH}$ ve DO'dan oluşmaktadır. İkinci faktör ise değişimlerin \%25'ini açıklarken $\mathrm{PO}_{4}-\mathrm{P}_{\text {ve }} \mathrm{NH}_{4}-\mathrm{N}$ 'den oluşmaktadır. Faktör analizine göre $\mathrm{NH}_{2}-\mathrm{N}$ ve $\mathrm{NH}_{3}-\mathrm{N}$ ile $\mathrm{PO}_{4}-\mathrm{P}$ ve $\mathrm{NH}_{4}$-N'ün farklı taşınma süreçlerine ve kaynaklara sahip olduğu anlaşılmaktadır.

\section{SONUÇ VE ÖNERILER}

Aktaş Gölü'nde 2014 yılı yaz aylarında yapılan çalışmadan elde edilen bulgular T.C. Tarım ve Orman Bakanlığı tarafindan yayınlanan Yüzeysel Su Kalitesi Yönetimi Yönetmeliği'nde belirtilen konsantrasyonlarla karşılaştırıldı̆̆ında; göl suyunun DO, $\mathrm{PO}_{4}-\mathrm{P}$ ve $\mathrm{NH}_{3}-\mathrm{N}$ açısından I. sınıf (kirlenmemiş), $\mathrm{NH}_{2}-\mathrm{N}$ açısından ise II. sınıfa (az kirlenmiş su) girdiği belirlenmiştir. Aktaş Gölü’nde örneklemesi 2004-2005 yılında gerçekleştirilen çalışmayla (Özbay ve Kılınç, 2008) yapılan karşılaştırmalara göre $\mathrm{PO}_{4}-\mathrm{P}$ ve $\mathrm{NH}_{4}-\mathrm{N}$ konsantrasyonunun geçen 10 yıllık periyotta oldukça arttığı tespit edilmiştir. Elde edilen bulgular değerlendirildiğinde; Aktaş Gölü yüzey sularında ekolojik sorunlara neden olacak bir bulguya rastlanmamıştır. Ancak, gölde 10 yıl önce yapılan bir çalışmada tespit edilen $\mathrm{PO}_{4}-\mathrm{P}$ ve $\mathrm{NH}_{4}-\mathrm{N}$ konsantrasyonunda artış gözlenmesi suyun ekolojik yapısında meydana gelebilecek muhtemel bozulmaların izlenmesi gerektiğini göstermektedir. Aktaş Gölü’nün su kalitesinin ve ekolojik yapısının bozulmaması için:

- Göl kenarında bulunan yerleşmelerin evsel atıklarının göle deşarj edilmemesi için gerekli denetimlerin yapılması,

- Özellikle kış ayları için biriktirilen tezeklerin depolamalarının yağmur suyuyla göle ulaşmasını engelleyecek şekilde yapılması,

- Gölden su içmek için büyük sürüler halinde sahile gelen büyükbaş hayvanların sulama alanlarının daha uzak bir yere konumlandirılması,

- Aktaş Sınır Kapısı'nın tekrar aktif olması halinde göl yakınından geçen kara yolunun yoğunlaşması durumunda gölde meydana gelebilecek ekolojik değişimlerin analitik metotlara dayanan çalışmalarla incelenmesi,

- Gürcistan sınırından göle deşarj olan kirleticilerin izlenmesi için özellikle Gürcistan sınırına yakın örnekleme noktalarından belirli aralıklarla örnekleme yapılarak gerekli analizlerin yapılması,

- Ekolojik yapının korunması amacıyla gölün bütününde yapılması planlanan bilimsel araştırmaların gerçekleştirilmesinde kullanılacak izinler için diplomatik işbirliği sağlanması,
- Gölün ulusal ve uluslararası koruma statülerinin güçlendirilmesi için gerekli çalışmaların yapılması önerilmektedir.

Teşekkür: Bu çalışma, Ardahan Üniversitesi, Bilimsel Araştırma Projeleri Birimi tarafindan 2014 - 02 nolu proje kapsamında desteklenmiştir. Destekleri için Ardahan Üniversitesi BAP birimine teşekkür ederiz. Meteorolojik verilerin temin edilmesinde desteğini gördüğümüz Doç. Dr. Muhammed Zeynel Öztürk'e teşekkür ederiz.

Hakem Değerlendirmesi: Dış bağımsız.

Çıkar Çatışması: Yazarlar çıkar çatışması bildirmemiştir.

Finansal Destek: Bu çalışma Ardahan Üniversitesi, Bilimsel Araştırmalar Proje Birimi tarafından 2014-02 nolu proje kapsamında desteklenmiştir.

Peer-review: Externally peer-reviewed.

Conflict of Interest: The authors have no conflict of interest to declare.

Grant Support: This study was supported by Ardahan University Scientific Research Project Unit, project numbered 2014-02.

\section{KAYNAKÇA/REFERENCES}

Akgül, G. (2008). Çıldır ve Aktaş Gölleri arasında kalan bölgenin floras1. Ot Sistematik Botanik Dergisi, 15(1), 37-70.

Aydın, O., Ünaldı, Ü. E., Duman, N., Çiçek, İ., ve Türkoğlu, N. (2017). Türkiye'de su kıtlığının mekânsal ölçekte değerlendirilmesi. Türk Coğrafya Dergisi, 68, 11-18.

Deniz, Z. A. ve Gönençgil, B. (2017). Türkiye sıcaklık ekstremlerindeki değişkenlikler. Coğrafya Dergisi, 35, 41-54.

Didinen, H., Boyacı, Y., ve Yegen, V. (2013). Beyşehir Gölü zooplankton yapıs1 ve bazı ekolojik özellikleri. Süleyman Demirel Üniversitesi Eğirdir Su Ürünleri Fakültesi Dergisi, 9(1), 31-43.

Doğanay, H. ve Zaman, S. (2006). Aktaş Gölü ve yakın çevresinin coğrafyas1. Türk Coğrafya Dergisi, 46, 23-39.

Falkenmark, M., Lundqvist, J., and Widstrand, C. (1989). Macro - scale water scarcity requires micro - scale approaches. Natural Resources Forum, 13, 258-267.

Güney, E. (2004). Türkiye Hidrocoğrafyası. İstanbul: Çantay Kitabevi. İnandık, H. (1965). Türkiye Gölleri (Morfolojik ve Hidrolojik Özellikler). İstanbul Üniversitesi, Coğrafya Enstitüsü Yayınları, No:44, s.75.

Kırar, T. M. (1990). Çıldır ve Aktaş Gölleri Civarı Jeomorfolojisi. (Yüksek Lisans Tezi) İstanbul Üniversitesi, Deniz Bilimleri ve Coğrafya Enstitüsü, İstanbul.

Kırpık, M. A., Altunoğlu, M. K. ve Tanrıkulu, D. (2019). Aktaş (Ardahan) Gölü ve çevresinin faunistik yapısı. Kafkas Üniversitesi Fen Bilimleri Enstitüsü Dergisi, 12(2), 89-95.

Kıvrak, E. ve Gürbüz, H. (2006). Tortum Gölü’nün (Erzurum) bentik alg florasının mevsimsel değişimi. Ege Üniversitesi Su Ürünleri Dergisi, 23(3), 307-313.

Koçman, A. (1979). Yukarı Kura Nehri Havzası'nın Fiziksel Coğrafyası. (Doktora Tezi). Atatürk Üniversitesi, Edebiyat Fakültesi, Erzurum. 
Kükrer, S. (2017). Pollution, source, and ecological risk assessment of trace elements in surface sediments of Lake Aktaş, NE Turkey. Human and Ecological Risk Assesment, 23(7), 1629-1644.

Lahn, E. (1948). Türkiye Gölleri'nin Jeolojisi ve Jeomorfolojisi Hakkında Bir Etüt. M.T.A Enstitüsü Yayınlarl, Seri B, No: 12, Ankara.

Lahn, E. (1949). Çıldır ve Aktaş Gölü’nün Jeolojisi Hakkında. Türkiye Jeoloji Bülteni, 2(1), 113-117.

Meyer, L. A., and Köster, M. (2000). Eutrophication of marine waters: effects on benthic microbial communities. Marine Pollution Bulletin, 41(1-6), 255-263.

Mis, D. Ö. ve Ustaoğlu, M. R. (2009). Gölcük Gölü’nün (Ödemiş, İzmir) zooplanktonu üzerine araştırmalar. Su Ürünleri Dergisi, 26(1), 19-27.

Mutlu, E., Kutlu , B., Demir, T. ve Yanık, T. (2018). Assessment of metal concentrations and physicochemical parameters in the waters of Lake Tecer. Kastamonu Univ., Journal of Forestry Faculty, 18(1), $1-10$.

Mutlu, E., Yanı,, T. ve Demir, T. (2013). Karagöl'ün (Hafik-Sivas) su kalitesinin incelenmesi. Alınteri Zirai Bilimler Dergisi, 24(1), 35-45.

MGM (2014), Meteoroloji Genel Müdürlüğü, Erişim Adresi: https:// www.mgm.gov.tr/

Özbay, H. ve Kılınç, Ş. (2008). Limnological studies on the transboundary turkish soda lake: Lake Aktaş. Fresenius Environmental Bulletin, 17(6), 722-731.

Öztürk, M. Z. ve Kılıç, H. (2018). Ardahan'da iklim parametrelerindeki değişimin zamansal analizi. Türk Coğrafya Dergisi, 70, 37-43.

Öztürk, M. Z., Gülden, Ç. ve Aydın, S. (2017). Köppen-Geiger iklim sınıflandırmasına göre Türkiye'nin iklim tipleri. Coğrafya Dergisi, $35,17-27$.
Strickland, J. and Parsons, T. (1972). A Practical Handbook of Seawater Analysis. Canada: Fisheries Research Board of Canada.

Şengörür , B. ve Demirel, A. (2002). Akgöl'de (Gölkent - Sakarya) ötrofikasyon ve su kalite sinıfının belirlenmesi. Sakarya Üniversitesi, Fen Bilimleri Enstitüsü Dergisi, 6(3), 1-8.

Şimşek, O. (2019). Çıldır ve Aktaş Gölleri havzasında bazı coğrafi gözlemler. BELGÜ (4), 104-127.

Taş, B. (2011). Gaga Gölü (Ordu, Türkiye) su kalitesinin incelenmesi. Karadeniz Fen Bilimleri Dergisi, 1(3), 43-61.

Teubner, K. and Dokulil, M. (2002). Ecological stoichiometry of TN: TP: SRSi in freshwaters: nutrient ratios and seasonal shifts in phytoplankton assemblages. Archiv fur Hydrobiologie, 154(4), 625-646.

Tarım ve Orman Bakanlığı, Yüzeysel Su Kalitesi Yönetimi Yönetmeliği (2021), Erişim Adresi: https://www.tarimorman.gov.tr/SYGM/ Belgeler/Ekosistem\%20Esas1\%C4\%B1\%20Su\%20Kalitesi.pdf

Uncumusaoğlu, A. A. (2018). Statistical assessment of water quality parameters for pollution source identification in Bektaş Pond (Sinop,Turkey). Global NEST Journal, 20(1), 151-160.

Ustaoğlu , F., Tepe, Y., Aydın, H. and Akbaş, A. (2020). Evaluation of surface water quality by multivariate statistical analyses and WQI: case of comlekci stream,(Giresun-Turkey). Fresenius Environmental Bulletin, 29(1), 167-177.

Ünlü, A., Çoban, F. ve Tunç, S. (2008). Hazar Gölü Su Kalitesinin Fiziksel ve İnorganik-kimyasal Parametreler Açısından İncelenmesi. Gazi Üniversitesi, Mühendislik - Mimarlık Fakültesi Dergisi, 23(1), 119-127.

Wood, R. (1975). Hydrobotanical Methods. Baltimore: University Park Press. 